\title{
Molecular detection and antimicrobial resistance of Aeromonas from houseflies (Musca domestica) in Iran
}

\author{
Detección molecular y resistencia antimicrobiana de Aeromonas \\ desde moscas domésticas (Musca domestica) en Irán
}

\author{
Davood Ommi, ${ }^{1}$ MD, Seyed Mohammadreza Hashemian, ${ }^{2}$ MD, Elahe Tajbakhsh, ${ }^{3}$ Ph.D, \\ Faham Khamesipour,4* DVM.
}

${ }^{1}$ Functional Neurosurgery Research Center, Shahid Beheshti University of Medical Sciences, Tehran, Iran. ${ }^{2}$ Chronic Respiratory Disease Research Center, National Research Institute of Tuberculosis and Lung Diseases (NRITLD), Shahid Beheshti University of Medical Sciences, Tehran, Iran. ${ }^{3}$ Department of Microbiology, Faculty of Basic Sciences, Shahrekord Branch, Islamic Azad University, Shahrekord, Iran. ${ }^{4}$ Young Researchers and Elite Club, Shahrekord Branch, Islamic Azad University, Shahrekord, Iran, P.O. Box 166. *Correspondence: dr_faham@yahoo.com; f.khamesipour@iaushk.ac.ir

Received: February 2015; Acepted: June 2015.

\begin{abstract}
Objective. This study aimed to report the molecular detection and antimicrobial resistance of Aeromonas among houseflies (Musca domestica) in Shahrekord and Isfahan provinces of Iran. Materials and methods. Flies were caught from household kitchens, cattle farms, animal hospitals, human hospitals, slaughter house and poultry farms and put in collection separate sterile tubes. Isolation was accomplished by culture of flies in alkaline peptone water followed by identification with Aeromonas-specific Polymerase Chain Reaction (PCR). Results. Out of 600 houseflies 73 (12.2\%) were infected with Aeromonas spp. Significantly higher frequencies of Aeromonas were isolated in Shahrekord province $(13.0 \% ; 39 / 300)$ than in Isfahan province $(11.3 \% ; 34 / 300)$. The recovery frequencies of the organisms were significantly lower in kitchens as compared to those in cattle farms and hospital wards which were similar. Higher proportions of infected flies were obtained during summer whereas low proportions were obtained during winter. Conclusions. It is concluded that houseflies do harbor diarrheagenic pathogens, including Aeromonas especially during summer. The carried organisms are resistant to a number of antimicrobials at different levels. Thus, future plans aimed at stemming infections caused by these organisms should take flies into account. Control efforts of infections caused by this particular bacterium should therefore take into account Musca domestica.
\end{abstract}

Key words: Pathogens, locations, Polymerase chain reaction, resistant, seasons (Source: CAB).

\section{RESUMEN}

Objetivo. Este estudio tuvo como objetivo informar de la detección molecular y resistencia antimicrobiana de Aeromonas entre moscas domésticas (Musca domestica) en las provincias de Shahrekord y Isfahan de Irán. Materiales y métodos. Las moscas fueron capturadas en las cocinas domésticas, granjas de ganado, hospitales de animales, hospitales humanos, mataderos y granjas avícolas y pusieron en tubos separados estériles de recolección. El aislamiento se llevó a cabo por cultivo de moscas en agua de peptona alcalina seguida por la identificación con la reacción en cadena de polimerasa Aeromonas-específica (PCR). Resultados. De 600 moscas domésticas 73 (12.2\%) estaban infectadas con Aeromonas spp. Se aislaron significativamente mayores frecuencias de Aeromonas 
en la provincia Shahrekord $(13.0 \% ; 39 / 300)$ que en la provincia de Isfahan $(11.3 \% ; 34 / 300)$. Las frecuencias de recuperación de los organismos fueron significativamente más bajos en las cocinas, en comparación con las granjas de ganado y salas de hospitales que fueron similares. Mayores proporciones de moscas infectadas se obtuvieron durante el verano mientras que bajas proporciones se obtuvieron durante el invierno. Conclusiones. Se concluye que las moscas domésticas no albergan patógenos diarreogénicos, incluyendo Aeromonas especialmente durante el verano. Los organismos llevadas a son resistentes a un número de antimicrobianos en diferentes niveles. Este modo, los planes futuros dirigidos a limitar las infecciones causadas por estos organismos deberían tomar en cuenta las moscas. Los esfuerzos de control de infecciones causadas por esta bacteria en particular, por lo tanto debería tener en cuenta Musca doméstica.

Palabras clave: Patógenos, ubicaciones, reacción en cadena de la polimerasa, resistente, temporadas (Fuente: $C A B$ ).

\section{INTRODUCTION}

Aeromonas is a diarrheagenic bacterium responsible for a number of zoonotic infections in humans. It is commonly found in aquatic environment in temperate and subtropical countries causing opportunistic infections in both aquatic and terrestrial animals. Some species of Aeromonas are known to be associated with human diseases affect the gastrointestinal tract such as gastroenteritis and extraintestinal infections $(1,2)$. Extra-intestinal infections caused by Aeromonas include empyema, urinary and biliary tract infections, bacteriaemia, peritonitis; and skin and soft-tissue infections (3-5).

House flies (Musca domestica) are known to be involved in the transmission of important bacterial agents causing human and animal infections $(6,7)$. The flies, having close association with different forms of excreta and decaying organic matters (7), represent a substantial public health risk whenever they have access to human food. Their body anatomy, secretions they make and their feeding habits enable the flies to pick up and disseminate several pathogens $(6,8)$. To that effect, a number of authors have detected bacterial pathogens, including Helicobacter pylori, Salmonella and Campylobacter from houseflies $(8,9)$. Consequently this study was conducted with the aim of prevalence of Aeromonas in the houseflies as determined by both culture and PCR method caught from Shahrekord and Isfahan provinces of Iran.

\section{MATERIALS AND METHODS}

Study area and design. This study was conducted in Isfahan $\left(32.6333^{\circ} \mathrm{N}, 51.6500^{\circ} \mathrm{E}\right)$ and Shahrekord $\left(32.3256^{\circ} \mathrm{N}, 50.8644^{\circ} \mathrm{E}\right)$ provinces located in central and Southwestern Iran respectively. Houseflies (Musca domestica) were captured from household kitchens $(n=4)$, cattle farms $(n=4)$, animal hospitals $(n=2)$, human hospitals $(n=4)$, slaughter houses $(n=2)$ and poultry farms $(n=2)$.

\section{INTRODUCCIÓN}

La aeromonas es una bacteria diarreogénica responsable de un gran número de infecciones zoonóticas en los seres humanos. Se encuentra comúnmente en ambientes acuáticos de los países templados y subtropicales y causan infecciones oportunistas en animales acuáticos y terrestres. Se conocen algunas especies de Aeromonas por estar asociadas con enfermedades humanas que afectan el tracto gastrointestinal tales como la gastroenteritis y las infecciones extra-intestinales $(1,2)$. Las infecciones extra-intestinales causadas por Aeromonas incluyen la empiema, las infecciones urinarias y de las vías biliares, la bacteriemia, la peritonitis y las infecciones de la piel y los tejidos blandos $(3,5)$.

Las moscas domésticas (Musca domestica) se conocen por estar involucradas en la transmisión de agentes bacterianos importantes que causan infecciones en humanos y animales $(6,7)$. Las moscas, que tienen estrecha relación con diferentes formas de las excretas y materias orgánicas en descomposición (7), representan un riesgo de salud pública importante cuando tienen acceso a la alimentación humana. Las partes de su cuerpo, sus secreciones y sus hábitos alimenticios les permiten recoger y difundir varios patógenos $(6,8)$. En este sentido, algunos autores han detectado patógenos bacteriales, incluyendo la helicobacter pylori, la salmonella y la Campylobacter en las moscas domésticas $(8,9)$. En consecuencia, este estudio se realizó con el objetivo de determinar la prevalencia de Aeromonas en las moscas domésticas, según se encontró en los cultivos y en el método de PCR, capturadas en Shahrekord y Isfahan, provincias de Irán.

\section{MATERIALES Y MÉTODOS}

Área de estudio y diseño. El estudio se realizó en Isfahan $\left(32.6333^{\circ} \mathrm{N}, 51.6500^{\circ} \mathrm{E}\right)$ y en Shahrekord $\left(32.3256^{\circ} \mathrm{N}, 50.8644^{\circ} \mathrm{E}\right)$, provincias localizadas en el centro y suroeste de Irán respectivamente. 
Sample collection. This study was conducted on 600 houseflies collected from important sites in Isfahan and Shahrekord provinces such as household kitchens, cattle farms, animal hospitals, human hospitals, slaughter houses and poultry farms. The flies were collected either by manual capture or by using sticky traps.

At the animal hospitals, flies were captured from the around animals, around yard hospitals and near a dumpster in the parking lot. At the farms (cattle farms and poultry farms), flies were trapped on or around animals, their faeces and their feed. At the human hospitals, flies were captured from the around yard hospitals and near a dumpster in the parking lot and near public room. At the household kitchens, flies were captured from the kitchen, the public dining room, and near a dumpster in the parking lot. At the slaughter houses, flies were captured from the slaughter houses and near a dumpster in the parking lot.

Following capture the fly samples were transported to the laboratory of Biotechnology Research Center at Islamic Azad University using separate sterile tubes to prevent any contamination due to mixing of the samples. In the laboratory, flies were identified and killed by refrigeration in $-20^{\circ} \mathrm{C}$ cold chamber. They were then placed in $5 \mathrm{ml}$ peptone water and left at room temperature for $5 \mathrm{hr}$ before being processed.

Isolation of bacteria from samples. Bacteria were isolated from both the peptone water solutions that contained fly samples and from the fly guts by the method described by Nayduch et al (10).

DNA extraction. Genomic DNA was extracted from all isolates using CinnaGen DNA extraction kit (Cinnagen, Tehran, Iran) according to the manufacturer's instructions. The extracted DNA was quantified by spectrophotometric measurement at a wavelength of $260 \mathrm{~nm}$ according to the method described by Sambrook and Russell (11). Extracted DNA samples were stored frozen at $-20^{\circ} \mathrm{C}$ until used for molecular analysis using Polymerase Chain Reaction (PCR) at the Biotechnology Research Center.

PCR assay. In order to confirm the presence of Aeromonas spp. PCR test was performed. Primers F: 5'-TAGCTTGCTACTTTTGCCGG-3' and R: 5' GACACAGGAACTCTGCACCG-3' were used to amplicons were the expected size of $800 \mathrm{bp}$ (10). Amplification reaction was carried out in a total volume of $25 \mu \mathrm{l}$, consisting of $1 \mu \mathrm{M}$ of each set of primers, $2 \mathrm{mM} \mathrm{Mgcl2,} 200 \mu \mathrm{M}$ dNTP, $5 \mu \mathrm{l}$ of 10X PCR buffer, $1 \mathrm{U}$ of Taq DNA polymerase (Fermentas, Germany) and $1 \mu \mathrm{g}$ of template DNA. Each PCR was run in a thermal cycler (Mastercycler
Las moscas domésticas (Musca domestica) fueron capturadas en cocinas caseras $(n=4)$, fincas ganaderas $(n=4)$, clínicas veterinarias $(n=2)$, hospitales $(n=4)$, mataderos $(n=2)$ y granjas avícolas $(n=2)$.

Recolección de las muestras. Este estudio se realizó sobre 600 moscas domésticas recogidas en las provincias de Isfahan y Shahrekord, en sitios esenciales tales como cocinas domésticas, fincas ganaderas, clínicas veterinarias, hospitales, mataderos y granjas avícolas. Las moscas se recolectaron bien por captura manual o mediante el uso de trampas con adhesivos.

En las clínicas veterinarias las moscas se capturaron cerca de los animales, alrededor de los patios y cerca de un contenedor de basura ubicado en el estacionamiento. En las granjas (fincas ganaderas y granjas avícolas) las moscas fueron atrapadas cerca de los animales, de sus heces y de su comida. En los hospitales las moscas fueron capturadas alrededor de los patios, cerca de un contenedor de basura ubicado en el estacionamiento y cerca de las salas públicas. En zona de las cocinas domésticas, las moscas fueron capturadas en la cocina, el comedor y cerca de un contenedor de basura ubicado en el estacionamiento. En los mataderos las moscas fueron capturadas en las zonas de sacrificio y cerca de un contenedor de basura ubicado en el estacionamiento.

Luego de la captura las moscas tomadas como muestra se transportaron al Laboratorio de Biotecnología del Centro de Investigación Biotecnológica de la Universidad Islámica de Azad, utilizando tubos estériles separados para prevenir alguna contaminación debido a la mezcla de las muestras. En el laboratorio las moscas se identificaron y se mataron por medio de refrigeración en una cámara de frío a $-20^{\circ} \mathrm{C}$. Luego se colocaron en $5 \mathrm{ml}$ de agua de peptona y se dejaron a temperatura ambiente durante 5 horas antes de ser procesadas.

\begin{abstract}
Aislamiento de las bacterias de las muestras. Las bacterias se aislaron de las soluciones de agua de peptona que contenían estas muestras y de sus intestinos según el método descrito por Nayduch y colaboradores (1910).
\end{abstract}

Extracción del ADN. El ADN genómico se extrajo de todos los aislados utilizando el kit de extracción de ADN CinnaGen (CinnaGen, Teherán, Irán) según las instrucciones del fabricante. El ADN extraído se cuantificó mediante medición espectrofotométrica a una longitud de onda de $260 \mathrm{~nm}$, de acuerdo con el método descrito por Sambrook y Russell (11). Las muestras de ADN extraídas se almacenaron congeladas a $-20^{\circ} \mathrm{C}$ hasta cuando se realizó el análisis molecular utilizando la Cadena de Reacción Polymerasa (PCR por sus siglas en inglés) en el Centro de Investigación Biotecnológica. 
Gradient, Eppendorf, Germany) under the following conditions: 2 min of initial denaturation at $94^{\circ} \mathrm{C}$, followed by 35 cycles of denaturation at $94^{\circ} \mathrm{C}$ for 15 seconds, annealing at $56^{\circ} \mathrm{C}$ for 15 seconds and extension at $72^{\circ}$ for 20 seconds. This was followed by final extension at $72^{\circ} \mathrm{C}$ for $2 \mathrm{~min}$ and then the products maintained at $4^{\circ} \mathrm{C}$ until processed (10). The amplified products were analyzed in $1.5 \%$ agarose gel. Electrode buffer was TBE (Tris-base $10.8 \mathrm{~g} 89 \mathrm{mM}$, Boric acid $5.5 \mathrm{~g} 2 \mathrm{mM}$, EDTA (pH 8.0) $4 \mathrm{ml}$ of $0.5 \mathrm{M}$ EDTA (pH8.0) combined all components in sufficient $\mathrm{H}_{2} \mathrm{O}$ and stirred to dissolve). Gels were stained with ethidium bromide. Aliquots of $10 \mu \mathrm{l}$ of PCR products were applied to the gel. Constant voltage of 80 for 20 min was used for products separation. After electrophoresis images were obtained in UVItec documentation systems (UK).

Antimicrobial resistance testing. Antimicrobial resistance testing was performed by Kirby-Bauer disc diffusion method on Mueller Hinton agar based on recommendations of CLSI (formerly the National Committee for Clinical Laboratory Standards) (12). The following Antimicrobial were used in this study: Ampicillin, Cefalothin, Chloramphenicol, Gentamicin, Kanamycin, Nalidixic acid, Tetracycline, Trimethoprim- Sulfamethoxazole, Amikacin, Carbenicillin, Neomycin, Ofloxacin, Rifampin, Tobramycin.

Statistical analysis. Statistical analysis was carried out using SPSS statistical software version 17.0 (SPSS Inc. Chicago, IL, USA). Descriptive statistics were computed to determine frequencies of fly samples positive for Aeromonas and frequencies of resistance to different antibimicrobials. Chi square test was used to determine significance of the observed differences in proportions.

\section{RESULTS}

Detection of the organisms among the flies. The overall recovery frequency of Aeromonas spp. from the captured houseflies $(n=600)$ was $12.2 \%$. The recovery frequencies of the organism in the specific provinces were $13.0 \%(39 / 300)$ for Shahrekord and $11.3 \%$ (34/300) for Isfahan. The observed difference in these proportions was not statistically significant. Table 1 shows the percentages of Aeromonas recovery from flies sampled in each of the six locations. The recovery frequencies were significantly higher in houseflies captured in animal hospitals and slaughter houses. The seasonal recovery frequencies of the organisms are shown in table 2 . The frequencies were significantly higher in summer and low during autumn $(p \leq 0.05)$.
Ensayo PCR. Para confirmarla presencia de Aeromonas spp. se realizó la prueba de PCR. Se utilizaron Partidores F: 5'-TAGCTTGCTACTITTGCCGG-3' y R: 5'-GACACAGGAACTCTGCACCG-3' para amplicones que fueron del tamaño esperado de 800 bp (10). La reacción de amplificación se llevó a cabo en un volumen total de $25 \mu \mathrm{l}$, consta de $1 \mu \mathrm{M}$ de cada set de partidores, $2 \mathrm{mM} \mathrm{MgCl}_{2}, 200 \mu \mathrm{M}$ dNTP, $5 \mu$ le solución reguladora 10X PCR, $1 \mathrm{U}$ de Taq ADN polimerasa (Fermentas, Alemania) y $1 \mu \mathrm{g}$ de patrón de ADN. Cada PCR se corrió en un termociclador (Mastercycler Gradient, Eppendorf, Alemania) bajo las siguientes condiciones: 2 minutos de desnaturalización inicial a $94^{\circ} \mathrm{C}$, seguido de 35 ciclos de desnaturalización a $94^{\circ} \mathrm{C}$ durante 15 segundos, recocido a $56^{\circ} \mathrm{C}$ durante 15 segundos y extensión a $72^{\circ} \mathrm{C}$ durante 20 segundos. A esto siguió la extensión final a $72^{\circ} \mathrm{C}$ durante 2 min y luego los productos se mantuvieron a $4^{\circ} \mathrm{C}$ hasta su procesamiento (10). Los productos amplificados se analizaron en $1.5 \%$ gel de agarosa. El búfer de electrodo esta conforado por TBE (Tris-base $89 \mathrm{mM}$ $10.8 \mathrm{~g}, 5.5 \mathrm{~g}$ de ácido bórico $2 \mathrm{mM}$ y $4 \mathrm{ml}$ de EDTA ( $\mathrm{pH}$ 8.0) $0.5 \mathrm{M}$; se combinaron todos los componentes en suficiente $\mathrm{H} 2 \mathrm{O}$ y se agitó para disolver). Los geles se tiñeron con bromuro de etidio. Se aplicaron alícuotas de $10 \mu \mathrm{l}$ de productos de PCR al gel. Se aplicó un voltaje constante de $80 \mathrm{~V}$ durante 20 minutos para la separación de los productos. Después se obtuvieron imágenes de electroforesis en los sistemas de documentación UVItec (Reino Unido).

Prueba de resistencia antimicrobiana. La prueba de resistencia antimicrobiana se realizó mediante el método de difusión en disco Kirby-Bauer en agar Mueller Hinton basado en las recomendaciones del CLSI (antes Comité Nacional de Normas para Laboratorio Clínico) (12). Se utilizaron los siguientes antimicrobianos en este estudio: ampicilina, cefalotina, cloranfenicol, gentamicina, kanamicina, ácido nalidíxico, tetraciclina, trimetoprima sulfametoxazol, amikacina, carbenicilina, neomicina, ofloxacina, rifampicina y tobramicina.

Análisis estadístico. El análisis estadístico se realizó utilizando el software estadístico SPSS versión 17.0 (SPSS Inc. Chicago, IL, EE.UU.). Se calculó la estadística descriptiva para determinar las frecuencias de las muestras positivas de moscas para Aeromonas y las frecuencias de resistencia a diferentes antimicrobianos. Se utilizó la prueba de Chi cuadrado para determinar la significancia de las diferencias observadas en las proporciones.

\section{RESULTADOS}

Detección de los organismos en las moscas. La frecuencia de recuperación global de Aeromonas spp. en las moscas domésticas capturadas $(n=600)$ fue $12.2 \%$. Las frecuencias de recuperación del organismo 
Table 1. Recovery frequencies of Aeromonas spp. from houseflies captured at different locations in Shahrekord and Isfahan provinces of Iran.

\begin{tabular}{cc}
\hline Location & $\begin{array}{c}\text { Proportion of Aeromonas in \% } \\
\text { (Number) }\end{array}$ \\
\hline Kitchens & $6.0(100)$ \\
Cattle farms & $15.0(100)$ \\
Poultry farms & $10.0(100)$ \\
Slaughter houses & $18.0(100)$ \\
Animal hospitals & $17.0(100)$ \\
Human hospitals & $7.0(100)$ \\
\hline
\end{tabular}

Antimicrobial resistance. Different proportions of Aeromonas spp. were found to be resistant to each of the antimicrobials tested (Table 3 ). Higher frequencies of resistance were observed for cefalothin, ampicillin, tetracycline and nalidixic acid.

Table 3. Antimicrobial resistance profiles of 73 housefly derived Aeromonas isolates against 14 antimicrobial agents.

\begin{tabular}{cc}
\hline Antimicrobial agent & $\begin{array}{c}\text { Proportion of resistant isolates in \% } \\
(\mathbf{n}=\mathbf{7 3})\end{array}$ \\
\hline Ampicillin & 68.5 \\
Amikacin & 30.1 \\
Carbenicillin & 31.5 \\
Cefalothin & 74.0 \\
Chloramphenicol & 31.5 \\
Gentamycin & 30.1 \\
Kanamycin & 41.1 \\
Nalidixic acid & 67.1 \\
Neomycin & 31.5 \\
Ofloxacin & 31.5 \\
Rifampin & 32.9 \\
Tetracycline & 68.5 \\
Tobramycin & 31.5 \\
Trimethoprim- & 39.7 \\
Sulfamethoxazole & \\
\hline
\end{tabular}

\section{DISCUSSION}

The present study demonstrates occurrence of Aeromonas (12.2\%) in houseflies in the different locations involved in fly sampling. It is likely that the flies picked the organisms from the surrounding environments which could be contaminated by either sick animals, insects, food, water and even human beings as a result of unhygienic practices.

It was noted in this study that houseflies derived from slaughter houses, cattle farms, poultry farms and animal hospitals were more frequently positive for Aeromonas spp. than those derived from household kitchens and human hospital wards; some of these differences being statistically significant. This could bring us to a suggestion that these different locations do differ in the extent of contamination with the bacterium. Household
Table 2. Recovery frequencies of Aeromonas spp. from houseflies captured during different seasons in Shahrekord and Isfahan provinces of Iran.

\begin{tabular}{cc}
\hline Season & Proportion of Aeromonas in \% (n) \\
\hline Spring & $12.7(150)$ \\
Summer & $26.7(150)$ \\
Autumn & $2.7(150)$ \\
Winter & $6.7(150)$ \\
\hline
\end{tabular}

en las provincias específicas fueron $13.0 \%$ (39/300) para Shahrekord y el 11.3\% (34/300) para Isfahán. La diferencia observada en estas proporciones no fue estadísticamente significativa. La Tabla 1 muestra los porcentajes de recuperación de Aeromonas en las moscas muestreadas en cada una de las seis localidades. Las frecuencias de recuperación fueron significativamente mayores en las moscas domésticas capturadas en las clínicas veterinarias y mataderos. Las frecuencias de recuperación estacionales de los organismos se muestran en la Tabla 2. Las frecuencias fueron significativamente más altas en verano y bajas durante el otoño $(p \leq 0.05)$.

Resistencia antimicrobiana. Se encontró que diferentes proporciones de Aeromonas spp. eran resistentes a cada uno de los antimicrobianos analizados (Tabla 3). Se observaron frecuencias más altas de resistencia para la cefalotina, ampicilina, tetraciclina y ácido nalidíxico.

\section{DISCUSIÓN}

El presente estudio demuestra la presencia de Aeromonas (12.2\%) en las moscas domésticas de las diferentes localidades donde se hizo el muestreo de la mosca. Es probable que estas recogieran los organismos de los ambientes circundantes que podrían estar contaminados por animales enfermos, insectos, alimentos, agua e incluso por seres humanos, como resultado de prácticas antihigiénicas.

Se observó en este estudio que las moscas domésticas derivadas de mataderos, fincas ganaderas, granjas avícolas y clínicas veterinarias fueron más frecuentemente positivas para Aeromonas spp. que las derivadas de las cocinas domésticas y las salas de hospitales; algunas de estas diferencias fueron estadísticamente significativas. Lo anterior nos podría llevar a sugerir que estos diferentes lugares tienen distinto grado de contaminación con la bacteria. Las cocinas de los hogares y las salas de los hospitales podrían estar menos contaminadas, ya que reciben mucha atención en términos de higiene debido a la naturaleza de los servicios que prestan. Por otro lado los mataderos, fincas ganaderas y granjas avícolas están siempre sometidos a la contaminación con materia fecal, que es un portador conocido de muchos patógenos bacterianos. 
kitchens and human hospital wards could be less contaminated as they receive much attention in terms of hygiene due to the nature of the services they provide. On the other hand slaughter houses, cattle farms and poultry farms are always subjected to contamination with fecal matter which is a well known carrier of many bacterial pathogens.

Our study investigated and revealed carriage of bacterial pathogens on both the external body parts and in the guts of houseflies. Some other studies which also involved investigations on both the external and internal body parts of the flies found that all these parts carried the organisms. These findings indicate that the flies may act as both mechanical and biological vectors of bacterial pathogens (13).

Hospital acquired infections are among the challenges that the medical professionals face. Their frequencies remain unacceptably high and are associated with excess morbidity, mortality and increased healthcare costs (14). Aeromonas spp. are among the responsible bacterial organisms for such infections, the common manifestation being bacteriaemia; more so in immunocompromised individuals (15). Our results, which show occurrence of Aeromonas in houseflies in hospital environments, are suggestive of the possibility that the flies play role in perpetuation of some of these infections. The flies are likely to disseminate the bacteria they carry to patients and/or workers through contaminating food and/or water.

Houseflies (Musca domestica) are of common occurrence in livestock farms with varying numbers depending on season. Their contamination with potential human and animal pathogens has been reported earlier $(6,8)$. In the current study the flies collected from cattle and poultry farms were found infected with Aeromonas. Our results and those obtained by other researchers elsewhere reveal exposure of the flies, in farm environments, to these and possibly other microorganisms.

Many infectious diseases in temperate countries display seasonality, exhibiting patterns associated with weather conditions (16-19). Such diseases display seasonal peaks in summer and alternating with low background levels of infection during winter (20-22). Understanding these seasonal trends in infectious diseases is important for improving disease surveillance and analysis of the seasonal differences in the risks for contracting those diseases. In the present study the
Nuestro estudio investigó y reveló el transporte de bacterias patógenas tanto en las partes externas del cuerpo, como en los intestinos de las moscas domésticas. Algunos otros estudios que también incluyeron investigaciones de las partes externas e internas del cuerpo de las moscas, encontraron que todas estas portan los organismos. Estos hallazgos indican que las moscas pueden actuar como vectores de transmisión mecánica y biológica de los patógenos bacterianos (13).

Las infecciones adquiridas en los hospitales son algunos de los desafíos que enfrentan los profesionales de la medicina. Sus frecuencias siguen siendo inaceptablemente altas y están relacionadas con el exceso de morbilidad, mortalidad y aumento de los costos de salud (14). Las Aeromonas spp. son algunos de los organismos bacterianos responsables de este tipo de infecciones, siendo la manifestación más común la bacteriemia, más aún en individuos inmunocomprometidos (15). Nuestros resultados, que muestran la ocurrencia de Aeromonas en las moscas domésticas en entornos hospitalarios, indican la posibilidad de que las moscas juegan un papel en la perpetuación de algunas de estas infecciones. Las moscas son propensas a transmitir las bacterias que portan a los pacientes y/o trabajadores a través de la contaminación de los alimentos y/o agua.

La cantidad de moscas domésticas (Musca domestica) que están presentes normalmente en las explotaciones ganaderas, depende de la temporada. Anteriormente se ha informado de su contaminación con potenciales patógenos humanos y animales $(6,8)$. En el presente estudio se encontraron infectadas con Aeromonas las moscas recogidas en las fincas ganaderas y las granjas avícolas. Nuestros resultados y los obtenidos por otros investigadores en otras partes revelan la exposición de las moscas, en ambientes agrícolas, a estos y posiblemente otros microorganismos.

Muchas de las enfermedades infecciosas en los países de clima templado presentan estacionalidad y exhiben patrones asociados con las condiciones climáticas (16-19). Estas enfermedades presentan picos estacionales en el verano y se alternan con bajos niveles de infección durante el invierno (20-22). La comprensión de estas tendencias de temporada en las enfermedades infecciosas es importante para mejorar la vigilancia de las enfermedades y el análisis de las diferencias estacionales en los riesgos de contraer esas enfermedades. En el presente estudio las frecuencias de detección de Aeromonas en las moscas fueron altas durante el verano y bajas durante el otoño. Estos hallazgos y los de trabajos anteriores sugieren que las condiciones climáticas pueden estar influyendo en las infecciones con estos organismos.

Publicaciones recientes han informado la aparición de resistencia antimicrobiana entre las especies de 
frequencies of detection of Aeromonas from flies were high during summer and low during autumn. These findings and those of earlier works suggest that climatic conditions may be influencing infections with these organisms.

Recent publications have reported occurrence of antimicrobials resistance among Aeromonas species isolated from different hosts $(1,15)$. This was also evident in the present study in which isolates of were resistant to a number of antimicrobials though at varying levels. Unlike observations by authors of the two studies $(1,15)$ who reported more than $90 \%$ susceptibility to cephalosporins, aminoglycosides, fluoroquinolones; in the present study susceptibility to these antibiotics stood at $<70 \%$. Although on the basis of in vitro studies fluoroquinolones as well as third and fourth generation cephalosporins are suggested to be the drugs of choice for treatment of severe Aeromonas bacteriaemia (15), medical practitioners still need to take into account the existing complexity of in vitroin vivo correlation in antimicrobial susceptibility profiles displayed by Aeromonas spp.

With the findings of this and other researches, houseflies may be considered as important vectors of bacteria causing gastrointestinal diseases including Aeromonas in the study area and possibly other parts of Iran. Control efforts of infections caused by this particular bacterium should therefore take into account Musca domestica. The carried organisms are resistant to a number of antimicrobials at different levels. Thus, future plans aimed at stemming infections caused by these organisms should take flies into account.

\section{Competing interests}

Authors declare that they have no competing interests.
Aeromonas aisladas de diferentes anfitriones $(1,15)$. Esto también se evidenció en el presente estudio en donde los aislados presentaron resistencia a un número de antimicrobianos aunque a diferentes niveles. A diferencia de las observaciones de los autores de los dos estudios $(1,15)$ quienes informaron más de $90 \%$ de susceptibilidad a cefalosporinas, aminoglucósidos y fluoroquinolonas; en el presente estudio la susceptibilidad a estos antibióticos se situó en $<70 \%$. Aunque con base en los estudios in vitro de las fluoroquinolonas así como de las cefalosporinas de tercera y cuarta generación, se sugieren los fármacos a elegir para el tratamiento de la bacteriemia Aeromonas severa (15), los médicos todavía tienen que tener en cuenta la complejidad existente en la correlación in vitro - in vivo de los perfiles de susceptibilidad antimicrobiana mostradas por las Aeromonas spp.

Con los resultados de esta y otras investigaciones, las moscas domésticas se pueden considerarse como importantes vectores de las bacterias causantes de enfermedades gastrointestinales, incluyendo las Aeromonas en las áreas de estudio y posiblemente en otras partes de Irán. Los esfuerzos para el control de las infecciones causadas por esta bacteria particular deben, por lo tanto, tener en cuenta a la Musca domestica. Los organismos transmitidos son resistentes a diversos antimicrobianos a diferentes niveles. Por lo tanto, los planes que en el futuro se orienten para detener las infecciones causadas por estos organismos deberán tomar en cuenta a las moscas.

\section{Conflicto de intereses}

Los autores declaran que no tienen conflicto de intereses.

\section{REFERENCES}

1. Parker JL, Shaw JG. Aeromonas spp. clinical microbiology and disease. J Infect 2011; 62(2):109-118.

2. Khamesipour F, Moradi M, Noshadi E, Momeni Shahraki M. Detection of the prevalence of Aeromonas hyrophila in shrimp samples by Polymerase Chain Reaction (PCR) and cultural method in the Iran. J Biodivers Environ Sci 2014; $4(2): 47-52$.
3. Chao CM, Gau SJ, Lai CC. Aeromonas genitourinary tract infection. J Infect 2012; 65(6):573-575.

4. Chao CM, Lai CC, Tsai HY, Wu CJ, Tang HJ, Ko WC, Hsueh PR. Pneumonia caused by Aeromonas species in Taiwan. Eur J Clin Microbiol Infect 2013; 32(8):1069-1075. 
5. Lin WT, Su SY, Lai CC, Tsai TC, Gau SJ, Chao CM. Peritonitis caused by Aeromonas species at a hospital in southern Taiwan. Int Med 2013; 52(22):2517-21.

6. Nazni WA, Seleena B, Lee HL, Jeffery J, Rogayah TAR, Sofian MA. Bacteria fauna from the house fly, Musca domestica (L.). Trop Biomed 2005; 22(2):225-231.

7. Hemmatinezhad B, Ommi D, Hafshejani TT, Khamesipour F. Molecular detection and antimicrobial resistance of Pseudomonas aeruginosa from houseflies (Musca domestica) in Iran. J Venom Anim Toxins Incl Trop Dis 2015; 30(21):18.

8. Nichlols GL. Fly transmission of Campylobacter. Emerg Infect Dis 2005; 11(3):361-364.

9. Wales AD, Carrique-Mas JJ, Rankin M, Bell B, Thind $\mathrm{BB}$, Davies RH. Review of the carriage of zoonotic bacteria by arthropods, with special reference to Salmonella in mites, flies and litter beetles. Zoonoses and Public Health 2010; 57(5):299-314.

10. Nayduch D, Honko A, Noblet GP, Stutzenberger F. Detection of Aeromonas caviae in the common housefly Musca domestica by culture and polymerase chain reaction. Epidemiol Infect 2001; 127(3):561-566.

11. Sambrook J, D Russell: Molecular Cloning. a Laboratory Manual, 3rd edn. Cold Spring Harbor, NY: Cold Spring Harbor Laboratory; 2001.

12. Standards NCFCL. Performance standards for antimicrobial disk and dilution susceptibility tests for bacteria isolated from animals; approved standard. A3 NdM- ed., 2 edition. Wayne, PA: National Committee for Clinical Laboratory Standards; 2008.

13. Humphrey T, O'Brien S, Madsen M. Campylobacters as zoonotic pathogens: A food production perspective. Int J Food Microbiol 2007; 117(3):237-257.
14. Kok J, O'Sullivan MV, Gilbert GL. Feedback to clinicians on preventable factors can reduce hospital onset Staphylococcus aureus bacteraemia rates. J Hosp Infect 2011; 79(2):108-114.

15. Tang HJ, Lai CC, Lin HL, Chao CM. Clinical Manifestations of Bacteremia Caused by Aeromonas Species in Southern Taiwan. PLoS One 2014; 9(3):e91642.

16. Green C, Krause D, Wylie J. Spatial analysis of Campylobacter infection in the Canadian province of Manitoba. Int J Health Geogr 2006; 5: 2. doi: 10.1186/1476-072X-5-2.

17. Naumova EN: Mystery of seasonality. Getting the rhythm of nature. J Public Health Policy 2006; 27(1):2-12.

18. Fisman DN. Seasonality of Infectious Diseases. Annu Rev Public Health 2007; 28:127-143.

19. Naumova EN, Jagai JS, Matyas B, DeMaria A, MacNeill IB, Griffiths JK. Seasonality in six enterically transmitted diseases and ambient temperature. Epidemiol Infect 2007; 135(2):281-292.

20. Kovats RS, Edwards SJ, Charron D, Cowden J, D'Souza RM, Ebi KL, et al. Climate variability and Campylobacter infection: an international study. Int J Biometeorol 2005; 49(4):207-214.

21. Meldrum RJ, Griffiths JK, Smith RM, Esnas MR. The seasonality of human Campylobacter infection and Campylobacter isolates from fresh, retail chicken in Wales. Epidemiol Infect 2005; 133(1):49-52.

22. Keegan VA, Majowicz SE, Pearl DL, Marshall BJ, Sittler N, Knowles L, Wilson JB. Epidemiology of enteric disease in C-EnterNet's pilot site - Waterloo region, Ontario, 1990 to 2004. CAN J Infect Dis Med 2009; 20(3):79-87. 